\title{
ACCESS REFORM DALAM KERANGKA REFORMA AGRARIA UNTUK MEWUJUDKAN KEADILAN SOSIAL
}

\author{
Muhammad Ilham Arisaputra \\ Fakultas Hukum Universitas Hasanuddin, Makassar \\ e-mail: ilhamarisaputra@gmail.com
}

\begin{abstract}
ABSTRAK
Pada hakekatnya, tujuan dilaksanakannya reformasi agraria adalah untuk meningkatkan kesejahteraan kaum tani miskin. Reforma agraria tidak hanya dipahami sebagai kebijakan untuk redistribusi tanah, tetapi juga sebagai proses yang lebih luas seperti akses ke sumber daya alam, keuangan/modal, teknologi, pasar barang dan tenaga kerja, dan juga distribusi kekuatan politik. Pemerataan penguasaan tanah di pedesaan sebagai hasil dari reformasi agraria akan menghasilkan peningkatan kesejahteraan warga desa yang pada umumnya petani gurem atau buruh tani. Reforma agraria memainkan peran penting dalam perang melawan kemiskinan pedesaan. Sasaran utama reforma agraria adalah terciptanya keadilan sosial yang ditandai dengan adanya keadilan agraria.
\end{abstract}

Kata Kunci: access reform, reforma agraria, keadilan sosial.

\section{ABSTRACT}

In essence, the purpose of the implementation of agrarian reformis to improve the welfare of the poor peasants. Agrarian reformis not only understood as a policy for there distribution of land, but also as abroader process such as access to natural resources, financial/capital, technology, goods and labor markets, and also the distribution of political power. Equitable distribution of land tenureinrural areas as a result of agrarian reform will result in an increase in the welfare of the villagers who are generally small farmers or farm laborers. Agrarian reform plays an important role in the fight against ruralpoverty. The main target of the agrarian reformis the creation of social justice that is characterized by the presence of agrarian justice. Keywords: access reform, agrarian reform, social justice.

\section{PENDAHULUAN}

Pasal 33 ayat (3) Undang-Undang Dasar Negara Republik Indonesia Tahun 1945 (selanjutnya disebut UUD NRI 1945) menggariskan bahwa bumi, air, dan kekayaan alam yang terkandung di dalamnya dikuasai oleh negara dan dipergunakan sebesarbesarnya untuk kemakmuran rakyat. Sebagai suatu norma kewenangan atau bevoegdheidsnorm, Pasal 33 ayat (3) tersebut telah mengatribusikan kewenangan kepada subyek hukum, dalam hal ini negara, untuk melakukan perbuatan hukum terhadap sumber daya alam (bumi, air serta kekayaan alam yang terkandung di dalamnya). ${ }^{1}$ Implementasi dari Pasal 33 ayat (3) UUD NRI 1945 kemudian lahir Undang-Undang Nomor 5 Tahun 1960 tentang Peraturan Dasar Pokok

\footnotetext{
${ }^{1}$ Urip Santoso, Hukum Agraria; Kajian Komprehensif Kencana Penada Media Group, Jakarta, 2012, h. 153-154.
}

Agraria atau dikenal Undang-Undang Pokok Agraria (selanjutnya disingkat UUPA).

Maria SW Sumardjono menyatakan untuk kajian yang dilakukan Tim Penyusun RUU Pengelolaan Sumber Daya Alam mencatat lima karakteristik peraturan perundang-undangan sektoral antara lain Orientasi pada eksploitasi, mengabaikan konservasi dan keberlanjutan fungsi sumber daya alam, digunakan sebagai alat pencapaian pertumbuhan ekonomi melalui peningkatan pendapatan dan devisa negara dan lebih berpihak pada pemodal besar, ideologi penguasaan dan pemanfaatan SDA terpusat pada negara sehingga bercorak sentralistik serta pengelolaan sumber daya alam yang sektoral berdampak terhadap koordinasi antar sektor yang lemah; 5. Tidak mengatur perlindungan hak asasi 
manusia (yang selanjutnya disebut dengan HAM) secara proporsional. ${ }^{2}$

Banyaknya undang-undang sektoral yang lahir tentunya menimbulkan permasalahan tersendiri, seperti terjadinya disharmonisasi antara undangundang yang satu dengan undang-undang yang lainnya akibat tidak samanya prinsip-prinsip yang digunakan dalam pembentukannya. Prinsip-prinsip yang terdapat di undang-undang sektoral yang lahir tersebut seharusnya sama dan sinkron antara satu sama lainnya, terkhusus dengan UUPA sebagai undangundang pokok agraria pertama yang lahir di Indonesia. Disharmonisasi yang ada tersebut berdampak pada adanya celah hukum yang memungkinkan eksploitasi sumber daya alam serta kemunduran kualitas sumber daya alam, ketidakadilan berupa terpinggirkannya hak masyarakat yang hidupnya terutama tergantung pada akses terhadap sumber daya alam seperti petani, nelayan, dan lain-lain. ${ }^{3}$

Pembaruan agraria atau yang lebih dikenal dengan sebutan nama reforma agraria atau agrarian reform merupakan ide/gagasan terbaik yang pernah lahir dalam rangka mengatasi persoalan tanah dan masalah pengelolaan terhadap sumber daya alam. Pada hakekatnya, tujuan dilaksanakannya reformasi agraria adalah meningkatkan kesejahteraan kaum tani miskin. Rehman Sobhan, ${ }^{4}$ setelah menganalisis program reformasi agraria yang telah berlangung di 36 negara di seluruh dunia, ia berkesimpulan bahwa bila sebuah negara ingin mewujudkan penghapusan kemiskinan di pedesaan serta mengakselerasikan segala pembangunan ekonomi, maka tidak ada alternatif lain selain melakukan reformasi agraria yang radikal. Reformasi terhadap agraria tersebut akan mendistribusikan kembali tanah-tanah secara merata bagi sebagian besar rakyat yang tak bertanah dan yang kekurangan tanah. Hal tersebut dengan sendirinya dapat menghapuskan secara total penguasaan tanah yang dominan dari kelas-kelas yang lama (feodal) maupun kelas-kelas yang baru (kapitalis) di pedesaan.

\footnotetext{
2 Maria SW Sumardjono, Penyempurnaan UUPA dan Sinkronisasi Kebijakan, http://www.kompas.com/kompascetak/0309/24/opini/576798.htm

3 Ibid.

4 Rehman Sobhan seorang ekonom terkemuka dari Bangladesh menganalisa reforma agraria di 36 negara dan dituangkan di dalam buku karyanya yang berjudul Agrarian Reform and Social Transformation: Preconditions for Development Tahun 1993. Lihat dalam Hiski Darmayana, Hakekat Reformasi Agraria, http://www.berdikarionline.com/ opini/20111231/hakekat-reformasi-agraria.html\#ixzz2waAPoLi8
}

Pemerataan penguasaan tanah di pedesaan sebagai hasil dari reformasi agraria akan menghasilkan peningkatan kesejahteraan warga desa yang pada umumnya petani gurem atau buruh tani. Peningkatan terhadap kesejahteraan tersebut akan menimbulkan konsekuensi peningkatan daya beli warga desa. Hal ini akan menjadi pasar potensial bagi produkproduk industri nasional, yang pada akhirnya dapat membantu proses industrialisasi nasional sebagai pondasi bagi kemandirian ekonomi bangsa.

Reforma agraria di Indonesia itu sendiri sebenarnya telah dimulai setelah lahirnya UUPA, pemerintah saat itu telah memfokuskan kegiatannya pada penataan dan redistribusi tanah pertanian yang dikenal dengan nama landreform yang merupakan inti dari agrarian reform. Landreform merupakan suatu kegiatan penataan kembali secara berkelanjutan, berkesinambungan dan teratur mengenai kepemilikan tanah, khususnya tanah pertanian. Objek dari agrarian reform bukan hanya sekedar pengaturan tanah, tetapi lebih luas lagi objek agrarian reform menitikberatkan pada pengaturan dan pengelolaan sumber daya alam.

Reforma agraria secara yuridis dimuat dalam UUPA, yakni dalam Pasal 7, Pasal 10, dan Pasal 17. Namun demikian, makna dari reforma agraria yang termuat dalam Pasal tersebut hanya sebatas landreform saja. Pasal 7 UUPA mengatur tentang larangan kepemilikan terhadap tanah yang melampaui batas. Kemudian Pasal 10 UUPA mengatur tentang kewajiban bagi setiap orang dan badan hukum yang mempunyai sesuatu hak atas tanah pertanian untuk mengerjakan atau mengusahakannya secara aktif dengan mencegah cara-cara pemerasan. Sedangkan Pasal 17 mengatur tentang luas maksimum dan/atau minimum tanah yang boleh dipunyai dengan sesuatu hak oleh satu keluarga atau badan hukum.

Pemerintah melalui Badan Pertanahan Nasional Republik Indonesia (yang selanjutnya disingkat BPN RI) telah gencar melaksanakan program landreform yang lebih berpihak kepada petani atau penggarap. Landreform tidak hanya menjadi dasar yang kokoh dan stabil bagi pembangunan ekonomi dan sosial, tetapi juga menjadi dasar bagi pengembangan kehidupan masyarakat yang demokratis. Program ini memberikan peluang terjadinya proses pembentukan modal di pedesaan yang menjadi dasar bagi proses 
industrialisasi yang kokoh. ${ }^{5}$ Pelaksanaan landreform dirasa tidak begitu lengkap jika tidak diikuti dengan kegiatan access reform yang berupa pembinaan dan fasilitasi pasca redistribusi tanah.

Pada Tahun 2001 lahir Ketetapan MPR RI Nomor IX/MPR/2001 tentang Pembaharuan Agraria dan Pengelolaan Sumber Daya Alam. ${ }^{6}$ Dalam konsideran menimbang huruf $\mathrm{c}$ dan d Ketetapan MPR RI Nomor IX/MPR/2001 ini menilai bahwa pengelolaan sumber daya agraria dan sumber daya alam yang berlangsung selama ini telah menimbulkan penurunan kualitas lingkungan, ketimpangan struktur penguasaan, pemilikan, penggunaan dan pemanfaatannya serta menimbulkan berbagai konflik. Selain itu, Ketetapan MPR ini juga menilai bahwa berbagai undangundang sektoral yang lahir saling tumpang tindih dan bertentangan sehingga perlu untuk diharmonisasikan. Pengelolaan sumber daya agraria dan sumber daya alam yang adil, berkelanjutan, dan ramah lingkungan harus segera dilakukan di Indonesia dengan cara terkoordinasi, terpadu, dan menampung dinamika, aspirasi, dan peran serta masyarakat.

Secara ideal, pengelolaan sumber daya alam seharusnya memberi manfaat bagi masyarakat secara adil dan berbagai pihak secara luas, karena sesuai mandat Pasal 33 ayat (3) UUD NRI 1945 menegaskan bahwa untuk sebesar-besarnya kemakmuran rakyat, secara berkeadilan dan berkelanjutan. Namun yang terjadi saat ini adalah pengelolaan sumber daya alam yang lebih menitikberatkan kepada eksploitasi besarbesaran terhadap sumber daya alam sebagai sumber devisa negara. Terlebih lagi bahwa akses terhadap pengelolaan sumber daya alam lebih diberikan kepada pemilik modal dan bahkan investor asing yang menyebabkan akses masyarakat umum terhadap pengelolaan sumber daya alam menjadi tertutup.

Reforma agraria tidak hanya dipahami sebagai kebijakan untuk redistribusi tanah, tetapi juga sebagai proses yang lebih luas seperti akses ke sumber daya alam, keuangan/modal, teknologi, pasar barang dan tenaga kerja, dan juga distribusi kekuatan politik.

\footnotetext{
${ }^{5}$ Bernhard Limbong (selanjutnya disebut Bernhard Limbong I), Konflik Pertanahan, Margaretha Pustaka, Jakarta, 2012, h. 171.

${ }^{6}$ Ketetapan MPR No. IX/MPR/2001 ini masih tetap berlaku sampai sekarang berdasarkan Pasal 4 Ketetapan MPR No. I/ MPR/2003 tentang Peninjauan terhadap Materi dan Status Hukum Ketetapan Majelis Permusyawaratan Rakyat Sementara dan Ketetapan Majelis Permusyawaratan Rakyat Republik Indonesia Tahun 1960 sampai dengan Tahun 2002.
}

Selain akses, reforma agraria juga merupakan bentuk regularisasi hak penggunaan dan hak milik area yang telah mereka tempati. ${ }^{7}$ Reforma agraria pada hakikatnya merupakan konsep landreform yang dilengkapi dengan konsep accesreform dan regulationreform. ${ }^{8}$ Pelaksanaan reforma agraria dapat berhasil hanya jika dilakukan dalam kerangka yang lebih luas, yakni menawarkan bukan hanya akses ke lahan, tetapi juga akses ke kredit, penyuluhan pedesaan, dan layanan lainnya. ${ }^{9}$

Berkaitan dengan pemaparan di atas, Ali Masykur Musa mengatakan bahwa kemandirian energi nasional sulit terwujud oleh karena selama ini pengelolaan sumber daya alam nasional banyak didonimasi oleh perusahaan asing. Saat ini asing menguasai 70 persen pertambangan minyak dan gas atau migas, 75 persen tambang batu bara, bauksit, nikel dan timah, 85 persen tambang tembaga dan emas, serta 50 persen menguasai perkebunan sawit. Pertamina dalam hal ini BUMN migas kita hanya menguasai 17 persen produksi dan cadangan migas nasional. Sementara 13 persen sisanya adalah share perusahaan-perusahaan swasta nasional. ${ }^{10}$ Kemudian data Badan Pertanahan Nasional (yang selanjutnya disebut dengan BPN) tahun 2010 menyatakan, sekitar $0,2 \%$ orang Indonesia menguasai $56 \%$ seluruh aset nasional, yang $87 \%$ di antara aset itu berupa tanah, sebanyak 7,2 juta hektar tanah yang dikuasai swasta secara sengaja ditelantarkan. Saat ini, pemerintah telah menunjuk secara sepihak luas kawasan hutan adalah 136,94 juta hektar. Padahal, sampai hari ini, kawasan yang ditunjuk sepihak tersebut masih menyisakan 121,74 juta hektar kawasan hutan yang belum ditata batas oleh pemerintah untuk ditetapkan sebagai kawasan hutan. ${ }^{11}$

Data tersebut di atas menunjukkan kurangnya akses masyarakat Indonesia dalam hal pengelolaan tanah dan sumber daya alam di Indonesia. Terlebih

\footnotetext{
${ }^{7}$ Bernhard Limbong (disebut Bernhard Limbong II), Reforma Agraria, Margaretha Pustaka, Jakarta, 2012, h. 2.

${ }^{8}$ Ibid, h. 4.

9 Ibid, h. 6.

${ }^{10}$ Ali Masykur Musa, anggota Badan Pemeriksa Keuangan Republik Indonesia, 70 Persen Tambang Migas RI Dikuasai Asing, http://ekbis.rmol.co/read/2013/08/05/120963/Duh,-70Persen-Tambang-Migas-RI-Dikuasai-Asing-

11 Laporan Akhir Tahun 2012 Konsorsium Pembaruan Agraria, Dirilis dalam Konferensi Pers Akhir Tahun Konsorsium Pembaruan Agraria pada tanggal 28 Desember 2012 di Sekretariat KPA, Jakarta, h. 5.
} 
lagi bahwa para investor dan pemilik modal yang mengelola tanah dan sumber daya alam di Indonesia tidak begitu memperhatikan perlindungan terhadap lingkungan dan ekosistemnya sehingga terkesan terjadi eksploitasi yang tidak sehat dalam pengelolaan tanah dan sumber daya alam di Indonesia.

\section{METODE}

Tipe dalam penelitian hukum ini adalah normatif, dan menggunakan pendekatan masalah yaitu: pendekatan undang-undang atau statute approach dan pendekatan konseptual atau conseptual approach . Dalam metode pendekatan perundang-undangan atau statute approach maka yang harus dipahami adalah hierarki dan asas-asas dalam peraturan perundangundangan. Dalam penelitian ini maka pengkajian dilakukan terhadap isi perundang-undangan dan pendekatan konseptual. Pendekatan Konseptual yang dianalisa adalah konsep keadilan dan acces reform Peraturan Perundang-undangan yang di analisa antara lain: Undang-Undang Dasar Negara Republik Indonesia Tahun 1945; Undang-Undang Nomor 5 Tahun 1960 tentang Peraturan Dasar Pokok Agraria; Undang-Undang Nomor 11 Tahun 2005 tentang Pengesahan International Convenant on Economic, Social, and Cultural Rights; UndangUndang Nomor 12 Tahun 2005 tentang Pengesahan International Convenant on Civil and Political Rights; Ketetapan MPR RI Nomor IX/MPR/2001 tentang Pembaruan Agraria dan Pengelolaan Sumber Daya Alam; Ketetapan MPR RI Nomor 1/MPR/2003 tentang Peninjauan terhadap Materi dan Status Hukum Ketetapan Majelis Permusyawaratan Rakyat Sementara dan Ketetapan Majelis Permusyawaratan Rakyat Republik Indonesia Tahun 1960-2002.

\section{PEMBAHASAN}

\section{Konsep Reforma Agraria}

Reforma Agraria adalah restrukturisasi atau penataan ulang susunan kepemilikan, penguasaan, dan penggunaan sumber-sumber agraria, khususnya tanah. Tujuannya adalah untuk mengubah susunan masyarakat warisan stelsel feodalisme dan kolonialisme menjadi susunan masyarakat yang adil dan merata. Secara etimologis reforma agraria berasal dari bahasa Spanyol, yang memiliki arti suatu upaya perubahan atau perombakan sosial yang dilakukan secara sadar, guna mentransformasikan struktur agraria ke arah sistem agraria yang lebih sehat dan merata bagi pengembangan pertanian dan kesejahteraan masyarakat desa. ${ }^{12}$ Istilah Pembaruan Agraria baru diperkenalkan di Tahun 2001, yakni sejak lahirnya Tap MPR Nomor IX/MPR/2001 tentang Pembaruan Agraria dan Pengelolaan Sumber Daya Alam, yang berarti bahwa istilah Reforma Agraria atau Agrarian Reform lebih dulu dikenal dalam wacana ilmiah dibandingkan istilah Pembaruan Agraria. ${ }^{13}$

Krishna Ghimire memberikan pengertian yang sama antara agrarian reform dan landreform. Ia mendefinisikan reformasi agraria atau landreform sebagai perubahan besar dalam struktur agraria yang membawa peningkatan akses petani miskin pada lahan serta kepastian penguasaan atau tenure bagi mereka yang menggarap lahan, termasuk juga akses pada input pertanian, pasar, serta jasa-jasa dan kebutuhan pendampingan lainnya. ${ }^{14}$ Reforma agraria merupakan suatu perubahan dalam struktur agraria dengan tujuan peningkatan akses kaum tani miskin akan penguasaan tanah dan untuk meningkatkan kesejahteraannya. ${ }^{15}$

Frithjof Kuhnen menandai reforma agraria sebagai tindakan untuk mengatasi hambatan pembangunan yang timbul karena adanya kecacatan dalam struktur agraria yang berlaku. ${ }^{16}$ Reforma agraria harus bermakna penataan ulang struktur penguasaan tanah yang mencakup redistribusi tanah dan pembatasan (pencegahan) konsentrasi penguasaan tanah dan bahkan dapat pula di dalamnya terkandung aksi-aksi untuk menata ulang sistem bagi hasil dalam kegiatan pertanian. ${ }^{17}$ Reforma agraria juga menyangkut jaminan kepemilikan bagi buruh tani, penyewa tenaga kerja, penghuni peternakan, dan petani penyewa yang memungkinkan para pekerja dan penyewa memiliki prospek yang lebih baik untuk menerima pinjaman sektor swasta, layanan infrastruktur dan dukungan pemerintah melalui perusahaan-perusahaan pedesaan

12 Gunawan Wiradi, Reformasi Agraria; Perjalanan yang Belum Berakhir, INSIST Press, Yogyakarta, 2000, h. 35.

${ }^{13}$ Bernhard Limbong II, Op.Cit., h. 26.

14 Lihat pendapat Krishna Ghimire dalam artikel Hakekat Reformasi Agraria, http://www.berdikarionline. com/opini/20111231/hakekat-reformasi-agraria. html\#ixzz2JY1hdWzT

${ }^{15}$ Bernhard Limbong II, Op.Cit., h. 27.

${ }^{16}$ Lihat pendapat Frithjof Kuhnen dalam Bernhard Limbong II, Ibid.

${ }^{17}$ Lihat pendapat A.P. Parlindungan dalam Bernhard Limbong II, Ibid, h. 28. 
sebagai pelengkap untuk pertanian dan peningkatan partisipasi masyarakat dalam keputusan pemerintah di daerah pedesaan.

Ben Cousins memberikan perbedaan antara agrarian reform dengan landreform. Landreform berkaitan dengan hak atas tanah dengan cirinya masing-masing, kekuatan dan distribusi.Sedangkan reforma agraria tidak terbatas pada konsep landreform tersebut, tetapi lebih luas mencakupi juga isu-isu karakter kelas dari hubungan antara produksi dan distribusi di bidang pertanian dan perusahaan yang terkait, dan bagaimana semua hal itu terhubung ke struktur kelas yang lebih luas. Dengan kata lain, reforma agraria berkaitan dengan kekuatan ekonomi dan politik dan hubungan antara keduanya.

Dengan demikian pada hakikatnya, konsep reforma agraria mencakup 3 (tiga) konsep, yakni: pertama, Konsep Landreform, yakni penataan kembali struktur penguasaan kepemilikan tanah yang lebih adil; kedua, Konsep Accesreform, yakni berkaitan dengan penataan penggunaan atau pemanfaatan tanah yang lebih produktif disertai penataan dukungan sarana dan prasarana yang memungkinkan petani memperoleh akses ke sumber ekonomi di wilayah pedesaan. Akses tersebut antara lain akses sarana dan prasarana pertanian, pengairan, jalan, usaha tani, pemasaran produksi, koperasi usaha tani, dan perbankan (kredit usaha rakyat); ketiga, Konsep Policy/Regulationreform, yakni berkenaan dengan pengaturan kebijakan dan hukum yang berpihak pada

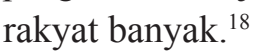

Ida Nurlinda memaparkan 10 prinsip dasar reforma agraria yakni: Pertama, Menjunjung tinggi hak asasi manusia, karena hak atas sumber-sumber agraria merupakan hak ekonomi setiap orang; Kedua, Unifikasi hukum yang mampu mengakomodasi keanekaragaman hukum setempat (pluralisme); Ketiga, Keadilan dalam penguasaan dan pemanfaatan sumber-sumber agraria (keadilan gender, keadilan dalam suatu generasi dan antar generasi, serta pengakuan kepemilikan masyarakat adat terhadap sumber-sumber agraria yang menjadi ruang hidupnya); Keempat, Fungsi sosial dan ekologi tanah serta sumber-sumber agraria lainnya, bahwa hak yang dipunyai seseorang menimbulkan kewajiban sosial bagi yang bersangkutan karena haknya dibatasi oleh hak orang lain dan hak masyarakat yang lebih luas; Kelima, Penyelesaian konflik pertanahan; Keenam,

$$
{ }^{18} \text { Ibid. }
$$

Pembagian tanggung jawab kepada daerah berkenaan dengan alokasi dan manajemen sumber-sumber agraria; Ketujuh, Transparansi dan partisipasi dalam pembuatan kebijakan hak; Kedelapan, Landreform atau restrukturisasi dalam pemilikan, penguasaan, pemanfaatan sumber-sumber agraria; Kesembilan, Usaha-usaha produksi di lapangan agraria; Kesepuluh, Pembiayaan program-program pembaruan agraria. ${ }^{19}$

Sedangkan prinsip-prinsip pembaruan agraria dan pengelolaan sumber daya alam sebagaimana termaktub dalam Pasal 4 Ketetapan MPR Nomor IX/MPR/2001 adalah sebagai berikut:

Pembaruan agraria dan pengelolaan sumber daya alam harus dilaksanakan sesuai dengan prinsipprinsip: pertama, Memelihara dan mempertahankan keutuhan Negara Kesatuan Republik Indonesia; kedua, Menghormati dan menjunjung tinggi hak asasi manusia; ketiga, Menghormati supremasi hukum dengan mengakomodasi keanekaragaman dalam unifikasi hukum; keempat, Mensejahterakan rakyat, terutama melalui peningkatan kualitas sumber daya manusia Indonesia; kelima, Mengembangkan demokrasi, kepatuhan hukum, transparansi dan optimalisasi partisipasi rakyat; keenam, Mewujudkan keadilan termasuk kesetaraan gender dalam penguasaan, pemilikan, penggunaan, pemanfaatan, dan pemeliharaan sumber daya agraria/sumber daya alam; ketujuh, Memelihara keberlanjutan yang dapat memberi manfaat yang optimal, baik untuk generasi sekarang maupun generasi mendatang, dengan tetap memperhatikan daya tampung dan daya dukung lingkungan; kedelapan, Melaksanakan fungsi sosial, kelestarian, dan fungsi ekologis sesuai dengan kondisi sosial budaya setempat; kesembilan, Meningkatkan keterpaduan dan koordinasi antarsektor pembangunan dan antar daerah dalam pelaksanaan pembaruan agraria dan pengelolaan sumber daya alam; kesepuluh, Mengakui, menghormati, dan melindungi hak masyarakat hukum adat dan keragaman budaya bangsa atas sumber daya agraria/sumber daya alam; kesebelas, Mengupayakan keseimbangan hak dan kewajiban negara, pemerintah (pusat, daerah propinsi, kabupaten/kota, dan desa atau yang setingkat), masyarakat dan individu; keduabelas, Melaksanakan desentralisasi berupa pembagian kewenangan di tingkat nasional, daerah propinsi, kabupaten/kota, dan desa atau yang setingkat.

${ }^{19}$ Ida Nurlinda, Prinsip-Prinsip Pembaruan Agraria Perspektif Hukum, RajaGrafindo Persada, Jakarta, 2009, h. 96. 
Berdasarkan prinsip-prinsip di atas tampak bahwa pembaruan agraria dan pengelolaan sumber daya alam dilaksanakan untuk sebesar-besarnya kemakmuran rakyat. Pembaruan agraria hampir secara universal dipandang sebagai suatu keniscayaan untuk membenahi persoalan sosial mendasar dalam masyarakat. Sebelum lahirnya Ketetapan MPR ini, UUPA telah mengamanatkan agar politik, arah, dan kebijakan agraria di Indonesia harus memberikan kontribusi nyata dalam proses mewujudkan keadilan sosial dan sebesar-besarnya kemakmuran bagi seluruh rakyat. Untuk itu, maka politik, arah, dan kebijakan agraria harus diarahkan pada 4 (empat) prinsip pengelolaan, yakni:

Pertama, Agraria, khususnya pertanahan harus berkontribusi nyata meningkatkan kesejahteraan rakyat dan melahirkan sumber baru kesejahteraan rakyat.

Kedua, Agraria, khususnya pertanahan harus berkontribusi nyata meningkatkan tatanan kehidupan bersama yang lebih berkeadilan dalam kaitannya dengan pemanfaatan, penggunaan, penguasaan, dan pemilikan tanah.

Ketiga, Agraria, khususnya pertanahan harus berkontribusi nyata menjamin keberlanjutan sistem kemasyarakatan, kebangsaan, dan kenegaraan Indonesia dengan memberikan akses seluas-luasnya pada generasi akan datang pada sumber-sumber ekonomi masyarakat, dalam hal ini tanah.

Keempat, Agraria, khususnya pertanahan harus berkontribusi nyata menciptakan tatanan kehidupan yang secara harmonis dengan mengatasi berbagai sengketa dan konflik pertanahan di seluruh tanah air dan menata sistem pengelolaan yang tidak lagi melahirkan sengketa dan konflik di kemudian hari. ${ }^{20}$

Reforma agraria di Indonesia dilaksanakan berdasarkan Ketetapan MPR RI Nomor IX/MPR/2001 tentang Pembaharuan Agraria dan Pengelolaan Sumber Daya Alam yang mengamanatkan kepada pemerintah antara lain untuk melaksanakan penataan kembali penguasaan, pemilikan, penggunaan dan pemanfaatan tanah yang berkeadilan dengan memperhatikan kepemilikan tanah untuk rakyat serta menyelesaikan konflik-konflik yang berkenaan dengan sumber daya alam yang timbul selama ini sekaligus mengantisipasi potensi konflik di masa

\footnotetext{
${ }^{20}$ Badan Pertanahan Nasional Republik Indonesia, Tanah untuk Keadilan dan Kesejahteraan Rakyat, BPN RI, Jakarta, 2010, h. 42-43.
}

mendatang guna menjamin terlaksananya penegakan hukum. Pasal 2 Ketetapan MPR RI Nomor IX/ MPR/2001 menegaskan bahwa Pembaruan Agraria adalah mencakup suatu proses berkesinambungan berkenaan dengan penataan kembali penguasaan, pemilikan, penggunaan dan pemanfaatan sumber daya agraria, dilaksanakan dalam rangka tercapainya kepastian dan perlindungan hukum serta keadilan dan kemakmuran bagi seluruh rakyat Indonesia.

Perkataan berkesinambungan pada Pasal 2 tersebut di atas berarti melihat pembaruan agraria masa lalu, masa kini dan masa akan datang. Setiap usaha pembaruan, jika ingin berhasil tidak boleh menutup mata mengenai apayang ada, apa yang ditinggalkan, dan sejarah pertumbuhannya. Produk hukum masa lalu yang sampai sekarang masih berlaku perlu peninjauan kembali untuk diverifikasi dan difalsifikasi apakah masih relevan dan cocok dengan kebutuhan sekarang dan masa yang akian datang. Berdasarkan hal ini, maka kemudian ditetapkan apa yang seharusnya dilakukan bagi tujuan masa yang akan datang melalui penafsiran yang futuristik. ${ }^{21}$ Berdasarkan Pasal 2 tersebut terlihat bahwa ada 2 (dua) bagian pokok, yakni aspek penguasaan dan pemilikan di satu sisi serta aspek penggunaan dan pemanfaatan di sisi lainnya. Aspek penguasaan dan pemilikan tersebut merupakan kegiatan utama landreform, sedangkan aspek penggunaan dan pemanfaatan merupakan kegiatan access reform.

\section{Keadilan Sosial}

Dalam perbincangan mengenai keadilan, keadilan sosial dipahami sebagai salah satu bagian atau jenis dari ragam keadilan yang ada. Black's Law Dictionary, social justice diartikan sebagai Justice that conforms to a moral principle, such as that all people are equal. ${ }^{22}$

Dengan demikian, dapat dimaknai bahwa keadilan sosial bukan persoalan moral individu, tetapi masalah moral sosial yang terkait dengan persoalanpersoalan struktural yang bersifat impersonal yang berarti bahwa pelaksanaan keadilan sosial tidak ditentukan oleh kehendak baik-buruk individu tertentu, tetapi bergantung kepada struktur-struktur

${ }^{21}$ Achmad Sodiki, Politik Hukum Agraria, Konstitusi Press, Jakarta, 2013, h. 37.

${ }^{22}$ Bryan A. Garner, Black's Law Dictionary, Eight Edition, A Thompson Business, West St. Paul, 2004, h. 881. 
kekusaan yang ada dalam masyarakat seperti struktur ekonomi, politik, dan budaya. ${ }^{23}$

Friedrich von Hayek menjelaskan bahwa The state ambition to realize social justice implies a centralized authority making people do things they might not want to do, interfering with their freedom to do what they like with their resources. ${ }^{24}$ Dengan demikian, dapat ditafsirkan bahwa keadilan sosial adalah suatu upaya penyediaan sumber daya yang dilakukan secara sengaja bagi kemaslahatan umum. Konsep keadilan sosial Friedrich von Hayek membedakan antara individu sebagai agent dan masyarakat sebagai society. Pada keadilan sosial terdapat suatu society yang berbeda dengan individu yang juga memiliki landasan eksistensi politik untuk terlibat dan bertindak.

Dari perspektif kemajemukan identitas dalam masyarakat, Nancy Fraser juga memaparkan makna keadilan sosial secara komprehensif. Menurut Nancy Fraser bahwa keadilan sosial mengacu pada 2 (dua) hal, yaitu masalah redistribusi dan masalah pengakuan. Kecenderungan yang muncul dalam perkembangan gagasan sosial-politik adalah memisahkan dan membedakan kedua jenis pandangan tersebut. Masalah redistribusi atau redistribution berfokus pada masalah ketidakadilan dalam kerangka sosial-ekonomi dan ketidakadilan tersebut berakar pada struktur ekonomi di masyarakat. Upaya untuk mengatasi persoalan tersebut mencakup program pemerataan pendapatan, pengaturan organisasi tenaga kerja, demokratisasi prosedur pembentukan kebijakan penanaman modal, atau mengubah struktur ekonomi dasar lainnya. ${ }^{25}$

Selanjutnya masalah pengakuan atau recognition memiliki sasaran ketidakadilan yang berada pada ranah budaya yang dianggap mengakar pada masalah yang bercorak sosial seperti masalah perwakilan atau representation, penafsiran atau interpretation, dan komunikasi atau communication. Upaya untuk mengatasi masalah ketidakadilan dalam pandangan ini

${ }^{23}$ Y. Slamet Purwadi, et.al., Pendidikan Nilai Pancasila, Unpar Press, Bandung, 2007, h. 139.

${ }^{24}$ Lihat pendapat Friedrich von Hayek dalam Adam Swift, Political Philosophy: A Beginner's Guide for Student and Politicians, Polity, Cambridge, 2006, h. 9.

${ }^{25}$ Nancy Fraser, Social Justice in The Age of Identity Politics: Redistribution, Recognition, and Participation, h. 6-7. www.intelligenceispower.com/important $\% 20$ E-mails $\% 20$ sent $\% 20$ attachment/Social\%20Justice\%20in\%20The $\% 20$ Age $\% 20$ of\%20Identity\%20Politics.pdf adalah berupa penghormatan terhadap identitas dan produk budaya dari kelompok yang termarginalkan, termasuk juga usaha untuk mengakui perbedaan budaya yang ada. Kesemuanya itu dilakukan menurut upaya pengubahan yang radikal terhadap corak sosial yang telah ada, yaitu transformasi bentuk dan cara perwakilan, penafsiran, dan komunikasi sehingga dapat mengubah kesadaran masyarakat akan keberagaman identitas. ${ }^{26}$

Gagasan keadilan sosial bersinggungan erat dengan hak asasi manusia, khususnya mengenai hak ekonomi, sosial, dan budaya sebagaimana terjabarkan dalam International Covenant on Social, Economic, and Cultural Rights Tahun 1966. Keadilan sosial berkaitan erat dengan hak-hak manusia terhadap segala sesuatu yang dapat menunjang kehidupannya. Sumber daya agraria merupakan sesuatu yang dapat menunjang kehidupan manusia sehingga penulis berpendapat bahwa gerakan reforma agraria merupakan gerakan untuk menciptakan keadilan sosial bagi seluruh rakyat Indonesia untuk mewujudkan kesejahteraan rakyat.

\section{Korelasi Access Reform dan Keadilan Sosial}

Kemiskinan dan ketidakadilan adalah dua hal yang sangat berkaitan, dimana ada kemiskinan, maka di situ terdapat pula ketidakadilan. Sebaliknya dimana ada ketidakadilan, maka di situ akan ada kemiskinan. Pemerintah Indonesia selama ini telah berusaha untuk menuntaskan kemiskinan dengan berbagai macam program, namun besarnya anggaran yang dikeluarkan untuk itu tidak sebanding dengan penurunan angka kemiskinan di Indonesia. Hal ini terjadi oleh karena kemiskinan dan ketidakadilan di Indonesia bersifat struktural yang tidak mempan lagi diselesaikan dengan cara lama, diperlukan suatu terobosan baru dan modern untuk mengurangi dan bahkan menghapus kemiskinan dan ketidakadilan di Indonesia. ${ }^{27}$

Achmad Sodiki menjelaskan bahwa keadilan sosial merupakan masalah universal manakala rakyat merasa tertindas. Ketika rakyat kehilangan tanahnya karena dicabut atau dibebaskan untuk kepentingan negara atau swasta dengan cara-cara yang sewenang-

${ }^{26}$ Ibid.

27 Joyo Winoto, Kepala Badan Pertanahan RI, Mulai Dari Selatan, lihat dalam Badan Pertanahan Nasional RI, Tanah untuk Keadilan dan Kesejahteraan Rakyat, Badan Pertanahan Nasional Republik Indonesia, 2010, h. 50. 
wenang, maka cepat atau lambat negara atau swasta akan menuai badai. Para perumus UUPA mengemukakan gagasannya untuk membela kaum tani dengan melancarkan gerakan land reform, maka selama lima tahun sejak diundangkannya UUPA, kendala utama pelaksanaannya adalah ketidaksiapan pemerintah melaksanakannya sehingga terkesan tidak ada political will yang kuat dari pemerintah. Antara kelompok tani yang satu dengan kelompok tani yang lain juga terjadi ketidakkompakan oleh karena terkait dengan garis politik partai yang membawahinya yang saling berebut pengaruh di antara mereka. Dengan demikian, maka semakin tidak jelas adanya program land reform yang merupakan wahana bagi penciptaan keadilan sosial. ${ }^{28}$

Menurut Joyo Winoto bahwa kemiskinan erat kaitannya dengan kepemilikan aset dan fakta menunjukkan bahwa orang miskin di Indonesia, sekitar $60-80 \%$ kekayaannya berupa tanah tapi belum disertifikasi. Akibatnya adalah masyarakat tidak dapat menggunakan asetnya itu sebagai alat untuk mendapatkan modal usaha. Penelitian di 157 negara menunjukkan pula bahwa aset terpenting bagi rakyat miskin adalah tanah, aset kedua adalah benda yang ada di sekitarnya, dan aset yang ketiga adalah aset sosial yang berupa ketergantungan pada keluarga dan tetangga. Dengan inilah, maka reforma agraria menjadi salah satu terobosan pemecahan masalah. ${ }^{29}$

Sebagaimana diketahui bahwa ada 3 (tiga) konsep reforma agraria, yakni Konsep Landreform, Konsep Accesreform, dan Konsep Policy atau Regulation reform. Pasal 2 Ketetapan MPR RI Nomor IX/MPR/2001 telah menggariskan bahwa pembaharuan Agraria adalah mencakup suatu proses berkesinambungan berkenaan dengan penataan kembali penguasaan, pemilikan, penggunaan dan pemanfaatan sumber daya agraria, dilaksanakan dalam rangka tercapainya kepastian dan perlindungan hukum serta keadilan dan kemakmuran bagi seluruh rakyat Indonesia. Dalam reforma agraria, ada dua hal yang diperhatikan, yakni akses ke tanah atau lahan dan akses ke instrumen penunjang tanah atau lahan. Akses ke tanah atau lahan merupakan konsep land reform, sedangkan akses ke instrumen penunjang lahan atau tanah merupakan konsep access reform.

\footnotetext{
${ }^{28}$ Achmad Sodiki, Op.Cit., h. 155-157.

${ }^{29}$ Lihat pendapat Joyo Winoto dalam BPN RI, Op.Cit.,
} h. 50 .
Dalam konteks access reform, pemerintah memberikan fasilitasi akses kepada masyarakat, baik ke tanah atau lahan maupun akses ke instrumen penunjang tanah atau lahan yang salah satunya adalah modal, baik dalam bentuk kredit maupun yang bersumber dari APBN atau APBD. Untuk pengusahaan tanah atau lahan tersebut sepenuhnya merupakan tanggung jawab pribadi masing-masing penerima manfaat. Dalam rangka pengusahaan tanah atau lahan tersebut, pemerintah bertindak sebagai pendamping dengan memberikan pembekalan ilmu pengetahuan dasar dan bantuan bimbingan teknis kepada penerima manfaat. Jadi dalam konteks access reform ini, pemerintah tidak lepas tangan, namun ke semua mekanisme pelaksanaannya dalam koridor tanggung jawab dan pengawasan pemerintah langsung, baik pemerintah pusat maupun pemerintah daerah.

Jadi, pada dasarnya access reform merupakan pemberian kesempatan yang seluas-luasnya kepada masyarakat untuk mengelola dan memanfaatkan sumber daya alam yang tersedia di bumi Indonesia dengan dukungan dan fasilitasi dari pemerintah berupa sarana dan prasarana pertanian, pengairan, jalan, usaha tani, pemasaran produksi, koperasi usaha tani, dan perbankan (kredit usaha rakyat). Accessreform yang dimaksud adalah berkaitan dengan penataan penggunaan atau pemanfaatan tanah yang lebih produktif disertai penataan dukungan sarana dan prasarana yang memungkinkan petani memperoleh akses ke sumber ekonomi di wilayah pedesaan.

Kehadiran undang-undang sektoral diharapkan mampu mendukung agenda-agenda reforma agraria, khususnya access reform. Namun dalam kenyataannya, kehadiran undang-undang sektoral menimbulkan konflik hukum baru di bidang keagrariaan. UUPA yang selama ini menjadi landasan bagi penguasaan dan penggunaan sumber daya agraria tidak didukung oleh berbagai undangundang sektoral yang saling mengatur sendirisendiri dan menciptakan hukum tersendiri. Undangundang Nomor 10 Tahun 2004 tentang Pembentukan Peraturan Perundang-undangan sebagaimana telah diganti dengan Undang-Undang Nomor 12 Tahun 2011 tentang Pembentukan Peraturan Perundangundangan tidak mengenal ketentuan mengenai payung hukum atau undang-undang yang bersifat payung hukum dalam hierarki peraturan perundangundangan sehingga tidak terlihat adanya pembedaan 
antara undang-undang sebagai payung dan undangundang yang bersifat organik. Dengan demikian, kedudukan UUPA yang sejatinya sebagai undangundang payung seakan-akan tidak lebih tinggi dengan undang-undang organik lainnya. Kondisi tersebut membawa konsekuensi hukum, yakni pembuatan undang-undang yang bersifat organik tidak lagi harus mengacu pada UUPA yang sejatinya dimaksudkan untuk menjadi payung hukum yang mengandung amanat pembuatan beberapa undang-undang sebagai pedoman pelaksanaan UUPA. ${ }^{30}$

Ketimpangan hukum yang terjadi dalam undang-undang menciptakan konflik baru di bidang keagrariaan yang semakin memperumit jalannya agenda-agenda reforma agraria. Belum lagi setelah kelahiran undang-undang sektoral yang kemudian melahirkan lagi aturan-aturan baru sebagai aturan pelaksanaan undang-undang sektoral. Pada akhirnya, upaya untuk melakukan penyeragaman terhadap peraturan-perundang-undangan yang ada sampai saat ini menjadi semakin rumit. Inilah mungkin yang disebut oleh sebagian kalangan dan pakar agraria bahwa reforma agraria bukan hanya sekedar land reform dan access reform, tetapi mencakup pula regulation reform.

Untuk menangani konflik-konflik di bidang keagrariaan, tidak lain hanya dengan melakukan regulation reform melalui unifikasi hukum atau pun dengan melakukan sinkronisasi dan harmonisasi peraturan perundang-undangan. Namun itu semua tidaklah cukup tanpa dibarengi dengan upaya untuk mensinergikan peraturan perundang-undangan yang dimaksud. Upaya untuk mensinergikan yang dimaksud di sini diartikan sebagai upaya untuk saling menguatkan antara peraturan perundang-undangan yang satu dengan peraturan perundang-undangan yang lain. Jadi bukan sekedar melakukan penyesuaian atau sinkronisasi dan penyelarasan atau harmonisasi kaidah hukum, tetapi juga penguatan atau sinergi kaidah hukum antara peraturan perundang-undangan yang satu dengan yang lainnya.

Achmad Sodiki menjelaskan bahwa persoalan unifikasi hukum dan keanekaragaman hukum sesungguhnya sudah dicoba diselesaikan oleh UUPA sehingga tujuan UUPA untuk mencapai hukum agraria yang satu, sederhana, menjamin kepastian hukum dan

\footnotetext{
${ }^{30}$ Elza Syarief, Menuntaskan Sengketa Tanah Melalui Pengadilan Khusus Pertanahan, Gramedia, Jakarta, 2012, h. 122 .
}

mampu membawa kemakmuran, kebahagiaan dan keadilan dapat segera tercapai. Melihat redaksi Pasal 4 huruf c Ketetapan MPR Nomor IX/MPR/2001, sesungguhnya tujuan unifikasi hukum masih dipertahankan dengan cara mengakomodasikan keanekaragaman, khususnya hak masyarakat adat dan keragaman budaya bangsa atas sumber daya agraria. ${ }^{31}$

Konflik peraturan perundang-undangan seharusnya dapat diselesaikan lewat asas-asas hukum yang lazim berlaku, misalnya hukum yang derajatnya lebih tinggi membatalkan hukum yang derajatnya lebih rendah atau lex superior derogat legi inferiori, hukum khusus membatalkan hukum umum atau lex specialis derogat legi generali, dan hukum yang kemudian membatalkan hukum yang terdahulu atau lex posterior derogat legi priori. Dalam hal terjadi tumpang tindih peraturan perundang-undangan atas suatu objek tertentu, maka dalam rangka sinkronisasi pengaturannya diperlukan lembaga atau instansi yang lebih tinggi yang mempunyai otoritas untuk menilai (verifikasi) atau mengusulkan pembatalan (falsifikasi) atas suatu peraturan yang dianggap bertentangan dengan asas-asas peraturan yang baik. Dalam hal penerapan asas-asas umum tersebut, maka perlu diadakan kajian yang sifatnya formal dan subtansial. Kajian formal sifatnya prosedural, yaitu apakah secara formal suatu hukum sudah dianggap sah. Sedangkan kajian subtansial mementingkan isinya, apakah sudah mengandung rasa keadilan, kepastian, ataukah kemanfaatan. Dalam hukum pertanahan dan hukum agraria, sejak dulu berlaku ketentuan lex simpronius, yaitu hukum pertanahan dan hukum agraria harus mementingkan rakyat jelata, bahwa hukum harus membantu orang-orang yang bodoh atau lex succurit ignoranti. ${ }^{32}$

Pembentukan aturan hukum yang baru tentu saja tidak selalu keliru karena hukum pun berfungsi sebagai a tool of social engineering. ${ }^{33}$ Sebagai instrumen pembaruan masyarakat atau agent of change, hukum harus sesuai dengan cita-cita keadilan sosial agar hukum dapat dipatuhi oleh masyarakat. ${ }^{34}$ Hukum yang baik adalah hukum yang dapat diterima

\footnotetext{
${ }^{31}$ Achmad Sodiki, Op.Cit., h. 39-40.

${ }^{32} \mathrm{Ibid}$, h. 44-45.

${ }^{33}$ Lihat pendapat Roscoe Pound dalam Abrar Saleng, Kapita Selekta Hukum Sumberdaya Alam, Membumi Publishing, Makassar, 2013, h. 13.

${ }^{34}$ Lihat pendapat Rom R. Tyler, Why People Obey The Law, Princeton University Press, Princeton and Oxford, New Jersey, 2006, h. 14, dalam Ibid.
} 
oleh masyarakat tanpa upaya penegakan (paksaan) melainkan sebagai suatu kebutuhan. Berkaitan dengan fungsi hukum tersebut, pembentuk undangundang (kekuasaan legislatif), melalui penafsiran atas makna Pasal 33 ayat (3) dan ayat (4) UUD NRI 1945 telah meletakkan landasan yuridis keadilan antar generasi atau intergeneration equity. Prinsipprinsip keadilan antar generasi meletakkan 3 (tiga) kewajiban mendasar bagi generasi sekarang dalam konservasi sumber daya alam, yaitu: Concervation of option, menjaga agar generasi mendatang dapat memilih kuantitas keanekaragaman sumber daya alam; Concervation of quality, menjaga kualitas lingkungan agar lestari; Concervation of access, menjamin generasi mendatang minimal memiliki akses yang sama dengan generasi sekarang atas titipan kekayaan alam ciptaan Tuhan Yang Maha Esa. ${ }^{35}$

Hukum Agraria Nasional berfungsi sebagai pengintegrasi. Hak menguasai negara atas bumi, air, ruang angkasa, dan kekayaan alam yang terkandung di dalamnya, sekalipun masih dalam konsep hak ulayat dalam tingkatan nasional, tetapi sifatnya lebih mencerminkan keseimbangan dengan hak individual. Perubahan keseimbangan ini diperlukan dalam rangka penguatan hak individual dalam masyarakat yang bersifat kolektif sehingga kecenderungan penyalahgunaan hak dengan dalih kepentingan kolektif atau kepentingan umum oleh penguasa dapat dicegah. Demikian pula asas tanah berfungsi sosial harus mendapatkan tafsir baru. Asas fungsi sosial pada mulanya merupakan perlawanan atas kemutlakan eigendomrecht atau hak eigendom dari corak masyarakat yang individualistis. Pada masyarakat individualistik terdapat penyalahgunaan hak karena adanya kemutlakan hak milik, sedangkan dalam masyarakat kolektif juga terdapat penyalahgunaan hak karena kemutlakan hak menguasai. ${ }^{36}$

Dalam konteks Indonesia, Pancasila sebagai falsafah dan dasar negara berfungsi sebagai filosofische gronslag dan common platform dalam kehidupan bernegara yang berperan sebagai penyangga konstitusi. Relevansi nilai-nilai Pancasila sebagai penguatan struktur hukum nasional tidak terlepas dari kedudukan Pancasila dalam praktek

\footnotetext{
${ }^{35}$ Lihat pendapat Haryanto Stefanus, Keadilan antar Generasi dan Hukum Lingkungan Indonesia, Harian Umum Kompas, 11 Januari 1996, h. 4 dalam Ibid.

${ }^{36}$ Achmad Sodiki, Op.Cit., h. 41-42.
}

ketatanegaraan dan kehidupan bangsa Indonesia, yaitu sebagai sistem moral dan etika, dasar negara dan ideologi bangsa. Sila kelima Pancasila yang menegaskan bahwa Keadilan sosial bagi seluruh rakyat Indonesia merupakan ujung harapan dari semua sila-sila lainnya. Oleh karena itu, perumusan sila kelima dalam Alinea IV Pembukaan UUD NRI 1945 diakhiri dengan kalimat, ... serta dengan mewujudkan suatu keadilan sosial bagi seluruh rakyat Indonesia.

Pelaksanaan reforma agraria yang berparadigma Pancasila melalui konsep landreform dan access reform-nya senantiasa digalakkan untuk mewujudkan keadilan sosial bagi seluruh rakyat Indonesia. Reforma Agraria mendasarkan diri pada sebuah proses distribusi yang adil atas suatu aset (dalam hal ini tanah). Tanah itu sendiri bagi kebanyakan manusia merupakan identitas yang melekat kepadanya status kebangsaan dan kenegaraannya. Terlebih bagi rakyat Indonesia, UUPA menyebutkan bahwa hubungan warga dengan tanahnya bersifat abadi dan asasi. Dari hubungan ini sangat berdampak kepada kesejahteraan, kemakmuran, keadilan, dan keberlanjutan, serta harmoni bangsa dan negara Indonesia. Untuk itu, maka Reforma Agraria tidak lain adalah untuk melanjutkan amanat UUD NRI 1945 di mana tanah dimanfaatkan sebesar-besarnya bagi kemakmuran rakyat. Hal ini mungkin karena negara memiliki kekuasaan atas seluruh bumi, air, dan ruang angkasa, maka dengan Reforma Agraria berarti negara telah mendorong proses tegaknya keadilan sosial yang dicita-citakan bangsa ini sejak merdeka. Reforma Agraria merupakan agenda yang harus menjadi mainstream bangsa Indonesia.

Keadilan sosial bukan hanya menjadi tanggung jawab negara untuk mewujudkannya, akan tetapi menjadi tanggung jawab bersama, yakni negara, pelaku ekonomi, dan rakyat secara keseluruhan. Negara dalam konteks ini bertindak sebagai fasilitator dan regulator serta wasit yang baik, jika perlu mengintervensinya agar supaya akses pemilikan, penguasaan, penggunaan, dan pemanfaatan tanah dan sumber daya alam bagi rakyat khususnya petani dan buruh tani semakin terbuka lebar dan tersedia dengan baik.

Reforma agraria melalui landreform dan access reform harus dilaksanakan oleh semua elemen, baik negara atau pemerintah, pelaku ekonomi, dan masyarakat secara keseluruhan. Negara bertindak 
sebagai pelaksana, fasilitator, regulator, dan wasit yang baik melalui intervensinya agar akses masyarakat (masyarakat miskin, khususnya petani dan buruh tani) berupa akses ke tanah/lahan dan sumber daya alam maupun akses ke instrumen penunjangnya semakin terbuka dan tersedia dengan baik. Pelaku ekonomi dan masyarakat harus pula mengambil peranan dimana mereka tidak hanya menjadi penerima manfaat dari negara sebagai pelayannya, tetapi mereka harus turut berperan serta dan turut aktif dalam menyukseskan agenda-agenda reforma agraria, baik sebagai mitra pemerintah maupun dalam mengawasi jalannya pelaksanaan agenda reforma agraria.

Untuk mengoperasionalkan konsep pembaruan agraria, maka diperlukan prinsip-prinsip yang menjadi landasan dan arahan yang mendasari pelaksanaannya. Prinsip tersebut haruslah bersifat holistik, komprehensif dan mampu menampung hal-hal pokok yang menjadi tujuan dari pembaruan agraria. Pasal 4 Ketetapan MPR Nomor IX/MPR/2001 tentang Pembaruan Agraria dan Pengelolaan Sumber Daya Alam telah menetapkan 12 prinsip pembaruan agraria dan pengelolaan sumber daya alam yang dimaksud. Prinsip-prinsip tersebut seharusnya menjadi acuan dalam penyusunan peraturan perundang-undangan agraria dan pengelolaan sumber daya alam. Hal ini membawa konsekuensi terhadap perlunya upaya pengkajian ulang dan harmonisasi terhadap berbagai peraturan perundang-undangan yang bersifat sektoral yang berkaitan dengan agraria dan sumber daya alam. Pada intinya ke-12 prinsip pembaruan agraria tersebut yang tertuang dalam Pasal 4 Ketetapan MRP Nomor IX/MPR/2001, jika diringkas maka akan berpangkal pada 3 (tiga) prinsip utama, yakni: pertama, Prinsip Demokratis, dalam dimensi kesetaraan antara pemerintah dengan rakyat, pemberdayaan masyarakat dan pengembangan good governance dalam penguasaan dan pemanfaatan sumber daya agraria; kedua, Prinsip Keadilan, dalam dimensi filosofis baik keadilan inter generasi maupun keadilan antar generasi dalam upaya mengakses sumber daya agraria; ketiga, Prinsip keberlanjutan, dalam dimensi kelestarian fungsi dan manfaat yang berdayaguna dan berhasilguna. ${ }^{37}$

${ }^{37}$ Maria S.W. Sumardjono, Transitional Justice atas Hak Sumber Daya Alam, sebagaimana dikutip dalam Komisi Nasional Hak Asasi Manusia, Keadilan dalam Masa Transisi, Komisi Nasional Hak Asasi Manusia, Jakarta, 2001, h. 7.
Prinsip-prinsip pembaruan agraria tersebut di atas saling terkait satu sama lainnya dan tidak dapat dipisahkan antara yang satu dengan yang lainnya. Dalam konteks permasalahan yang dihadapi Indonesia saat ini, maka demokrasi harus dapat mengakhiri dan atau mengoreksi ketidakadilan struktural dalam penguasaan, pemilikan, penggunaan, dan pemanfaatan tanah dan sumber daya agraria lainnya. Dari segi hak asasi manusia, maka hal tersebut merupakan bentuk pelanggaran atas hakhak sipil, politik, ekonomi, sosial, dan budaya bagi rakyat Indonesia yang termarginalkan oleh peraturan perundang-undangan dan kebijakan negara di bidang pertanahan dan sumber daya agraria. Dalam Article 25 International Covenant on Economic, Social, and Cultural Rights yang telah diratifikasi ke dalam Undang-Undang Nomor 11 Tahun 2005 tentang Pengesahan International Covenant on Economic, Social, and Cultural Rights atau Kovenan Internasional tentang Hak-Hak Ekonomi, Sosial dan Budaya (LNRI Tahun 2005 Nomor 118 dan TLNRI Nomor 4557), maupun dalam Article 47 International Covenant on Civil and Political Rights yang telah diratifikasi dalam Undang-Undang Nomor 12 Tahun 2005 tentang Pengesahan International Covenant on Civil and Political Rights atau Kovenan Internasional tentang Hak-Hak Sipil dan Politik (LNRI Tahun 2005 Nomor 119 dan TLNRI Nomor 4558), menegaskan bahwa Nothing in the present covenant shall be interpreted as impairing the inherent rights of all peoples to enjoy and utilize fully and freely their natural wealth and resources.

Atas dasar ketentuan di atas, maka dalam kaitannya dengan hak-hak penguasaan, pemilikan, penggunaan, dan pemanfaatan tanah dan sumber daya agraria lainnya, pelaksanaan pengakuan, penghormatan dan perlindungan hak-hak sipil, politik, ekonomi, sosial, dan budaya tersebut tidak boleh ditafsirkan sebagai mengurangi hak-hak yang melekat pada seluruh masyarakat untuk menikmati secara penuh dan bebas atas kekayaan sumber daya alam mereka. Dengan demikian, maka tidak mungkin membangun demokrasi dan keadilan tanpa upaya pembaruan agraria sehingga pembaruan agraria merupakan suatu keniscayaan bagi negara yang sedang membangun seperti Indonesia. Jika dipahami bahwa pembaruan agraria merupakan suatu upaya restrukturisasi penguasaan, pemilikan, penggunaan, dan pemanfaatan tanah dan sumber daya agraria 
lainnya, maka prinsip-prinsip demokrasi, keadilan, dan keberlanjutan harus menjadi landasan segala upaya restrukturisasi.

Sesungguhnya reforma agraria yang berhasil adalah yang menempatkannya sebagai dasar bagi pembangunan ekonomi secara nasional yang kemudian menjadikannya basis penting bagi pertumbuhan industri nasional yang kuat. Dalam hal ini Reforma Agraria dapat diartikan sebagai suatu upaya sistematik, terencana, dan dilakukan secara relatif cepat, dalam jangka waktu tertentu dan terbatas, untuk menciptakan kesejahteraan dan keadilan sosial serta menjadi pembuka jalan bagi pembentukan masyarakat baru yang demokratis dan berkeadilan, yang dimulai dengan langkah menata ulang pemilikan, penguasaan, penggunaan, dan pemanfaatan tanah dan sumber daya alam, kemudian disusul dengan sejumlah program pendukung lain untuk meningkatkan produktivitas petani secara khusus dan perekonomian rakyat secara umum.

Penataan ulang struktur penguasaan tanah atau landreform bukan saja akan memberikan kesempatan kepada sebagian besar penduduk yang masih menggantungkan hidupnya pada kegiatan pertanian untuk meningkatkan taraf kehidupannya. Lebih dari itu, land eform akan menjadi suatu dasar yang kokoh dan stabil bagi pembangunan ekonomi dan sosial, dan juga menjadi dasar bagi pengembangan kehidupan masyarakat yang demokratis. Program ini akan membuka kesempatan untuk terjadinya proses pembentukan modal atau capital formation di pedesaan yang akan menjadi dasar bagi proses industrialisasi yang kokoh. Selain itu, ia juga akan memberikan sejumput kekuasaan pada kelompokkelompok petani miskin di pedesaan di dalam ikatanikatan sosial pada masyarakatnya. Memberikan tanah kepada para petani miskin yang selama ini terpinggirkan adalah salah satucara yang efektif untuk menggeser ketidakseimbangan di dalam struktur kekuasaan yang kemudian dapat menjadi dasar bagi pengembangan institusi-institusi sosial dan politik yang lebih partisipatoris, baik di tingkat lokal dan nasional, sekaligus memperkuat demokrasi. Tetapi tidak boleh diabaikan bahwa di dalam land reform selain ada proses redistribusi tanah bagi petani-petani miskin, tak bertanah, atau yang hanya menguasai lahan sedikit, harus terkandung muatan aksi-aksi untuk mencegah dan mengurangi konsentrasi penguasaan tanah.
Reforma agraria selain merupakan bagian dari program pembangunan ekonomi, juga bermakna sebagai suatu program politik untuk merubah struktur kekuasaan dalam lapangan agraria, atau penguasaan dan penggunaan sumber-sumber agraria. Di dalamnya, redistribusi tanah dan sumber-sumber agraria lainnya yang telah dikuasai dalam skala besar atau melebihi batas maksimum yang ditentukan dan pengembalian tanah-tanah dan sumber-sumber agraria lainnya yang diambil dari penguasaan rakyat sebelumnya, menjadi satu program penting dalam rangka merombak struktur penguasaan tanah atau sumber-sumber agraria tersebut. ${ }^{38}$

Reforma agraria akan menghasilkan revitalisasi sektor pertanian dan pedesaan yang kokoh. Reforma agrariayang berhasil ditandai oleh kepastian penguasaan tanah yang menjamin penghidupan dan kesempatan kerja bagi petani, tata-guna tanah yang mampu memperbaiki pengelolaan sumber daya alam dan pelestarian mutu lingkungan hidup, kedaulatan pangan, kemampuan produktivitas yang mampu membuat keluarga petani mampu melakukan re-investasi dan memiliki daya beli yang tinggi. Kalau hal ini terjadi, sektor pertanian di Indonesia akan menjadi sandaran hidup mayoritas rakyat dan juga sekaligus penyokong industrialisasi nasional. Dengan demikian reforma agrariaakan mewujudkan keadilan, kesejahteraan dan keamananan. Dengan kata lain bahwa tujuan pokok dari reforma agraria adalah penciptaan keadilan sosial yang ditandai dengan adanya keadilan agraria atau agrarian justice, peningkatan produktivitas, dan peningkatan kesejahteraan rakyat. Keadilan agraria itu sendiri dapat dimaknai sebagai suatu kondisi dimana struktur penguasaan tanah secara relatif tidak memperlihatkan ketimpangan, yang memberikan peluang bagi terciptanya penyebaran dan penguatan aktivitas perekonomian rakyat yang berbasis di pedesaan, dan kemudian menjadi basis bagi partisipasi aktif dan produktif bagi sebagian besar penduduk yang nyatanya bergantung pada aktivitas pertanian untuk terlibat dalam kegiatan pembangunan nasional, baik secara sosial, ekonomi, maupun politik. Itu sebabnya pula, sejak lama banyak ahli meyakini bahwa reforma agraria yang sejati akan memberikan kontribusi

38 Dianto Bachriadi, Reforma Agraria untuk Indonesia; Pandangan Kritis tentang Program Pembaruan Agraria Nasional (PPAN) atau Redistribusi Tanah ala Pemerintahan SBY, Tulisan untuk bahan diskusi dalam Pertemuan Organisasi-organisasi Rakyat se-Jawa di Magelang tanggal 6-7 Juni 2007, h. 6. 
penting bagi proses demokratisasi pedesaan yang dalam konteks Indonesia adalah salah satu pangkalan penting bagi kehidupan sosial sebagian besar penduduknya.

\section{PENUTUP}

Dalam konteks access reform, pemerintah memberikan fasilitasi akses kepada masyarakat, baik ke tanah/lahan maupun akses ke instrumen penunjang tanah/lahan yang salah satunya adalah modal, baik dalam bentuk kredit maupun yang bersumber dari APBN/APBD. Untuk pengusahaan tanah/lahan tersebut sepenuhnya merupakan tanggung jawab pribadi masing-masing penerima manfaat. Dalam rangka pengusahaan tanah/lahan tersebut, pemerintah bertindak sebagai pendamping dengan memberikan pembekalan ilmu pengetahuan dasar dan bantuan bimbingan teknis kepada penerima manfaat. Untuk menangani konflik-konflik di bidang keagrariaan, tidak lain hanya dengan melakukan regulation reform melalui unifikasi hukum atau pun dengan melakukan sinkronisasi dan harmonisasi peraturan perundang-undangan. Reforma agraria memainkan peran penting dalam perang melawan kemiskinan pedesaan serta dalam promosi pembangunan berkelanjutan yang berbasis luas. Sasaran utama reforma agraria adalah terciptanya keadilan sosial yang ditandai dengan adanya keadilan agraria (agrarian justice), peningkatan produktivitas dan peningkatan kesejahteraan rakyat.

Reforma agraria akan menghasilkan revitalisasi sektor pertanian dan pedesaan yang kokoh. Untuk menguatkan pelaksanaan reforma agraria di Indonesia yang bertujuan untuk mensejahterakan rakyat dan menciptakan keadilan sosial bagi seluruh rakyat Indonesia, maka nasionalisasi pengelolaan sumber daya alam sangat perlu untuk dilaksanakan. Nasionalisasi pengelolaan sumber daya alam ini dimulai dari proses nasionalisasi perusahaanperusahaan asing yang menguasai sumber daya alam di Indonesia.

\section{DAFTAR PUSTAKA}

\section{Peraturan Perundang-undangan:}

Undang-Undang Dasar Negara Republik Indonesia Tahun 1945.

Undang-Undang Nomor 5 Tahun 1960 tentang Peraturan Dasar Pokok Agraria.
Undang-Undang Nomor 11 Tahun 2005 tentang Pengesahan International Convenant on Economic, Social, and Cultural Rights.

Undang-Undang Nomor 12 Tahun 2005 tentang Pengesahan International Convenant on Civil and Political Rights.

Ketetapan MPR RI Nomor IX/MPR/2001 tentang Pembaruan Agraria dan Pengelolaan Sumber Daya Alam.

Ketetapan MPR RI Nomor 1/MPR/2003 tentang Peninjauan terhadap Materi dan Status Hukum Ketetapan Majelis Permusyawaratan Rakyat Sementara dan Ketetapan Majelis Permusyawaratan Rakyat Republik Indonesia Tahun 1960-2002.

\section{Buku:}

Saleng, Abrar, 2013, Kapita Selekta Hukum Sumberdaya Alam, Makassar: Membumi Publishing.

Sodiki, Achmad, 2013, Politik Hukum Agraria, Jakarta: Konstitusi Press.

Swift, Adam, 2006, Political Philosophy: A Beginner's Guide for Student and Politicians, Cambridge: Polity.

Badan Pertanahan Nasional Republik Indonesia, 2010, Tanah untuk Keadilan dan Kesejahteraan Rakyat, Jakarta: BPN RI.

Garner, Bryan A., 2004, Black's Law Dictionary, Eight Edition, A Thompson Business: West, St. Paul.

Limbong, Bernhard, 2012, Konflik Pertanahan, Jakarta: Margaretha Pustaka. , 2012, Reforma Agraria, Jakarta: Margaretha Pustaka.

Syarief, Elza, 2012, Menuntaskan Sengketa Tanah melalui Pengadilan Khusus Pertanahan, Jakarta: Gramedia.

Wiradi, Gunawan, 2000, Reformasi Agraria; Perjalanan yang Belum Berakhir, Yogyakarta: INSIST Press.

Nurlinda, Ida, 2009, Prinsip-Prinsip Pembaruan Agraria PerspektifHukum, Jakarta: RajaGrafindo Persada.

Komisi Nasional Hak Asasi Manusia, 2001, Keadilan dalam Masa Transisi, Jakarta: Komisi Nasional Hak Asasi Manusia. 
Santoso, Urip, 2012, Hukum Agraria; Kajian Komprehensif, Jakarta: Kencana Penada Media Group.

Purwadi, Y. Slamet, et.al., 2007, Pendidikan Nilai Pancasila, Bandung: Unpar Press.

\section{Tulisan Lain:}

Dianto Bachriadi, Reforma Agraria untuk Indonesia; Pandangan Kritis tentang Program Pembaruan Agraria Nasional (PPAN) atau Redistribusi Tanah ala Pemerintahan SBY, Tulisan untuk bahan diskusi dalam Pertemuan Organisasiorganisasi Rakyat se-Jawa di Magelang tanggal 6-7 Juni 2007.

Konsorsium Pembaruan Agraria, Laporan Akhir Tahun 2012, Dirilis dalam Konferensi Pers Akhir Tahun Konsorsium Pembaruan Agraria pada tanggal 28 Desember 2012 di Sekretariat KPA, Jakarta.

\section{Website:}

Darmayana, Hiski, Hakekat Reformasi Agraria, Sumber: http://www.berdikarionline.com/ opini/20111231/hakekat-reformasi-agraria. html\#ixzz2waAPoLi8

Fraser, Nancy, Social Justice in The Age of Identity Politics: Redistribution, Recognition, and Participation, Sumber: www.intelligenceispower. com/important $\% 20$ E-mails $\% 20$ sent $\% 20$ attachment/Social\%20Justice\%20in\%20The $\% 20$ Age $\% 20$ of\%20Identity\%20Politics.pdf

Ghimire, Krishna, Hakekat Reformasi Agraria, Sumber: http://www.berdikarionline.com/ opini/20111231/hakekat-reformasi-agraria. html\#ixzz2JY1hdWzT

Musa, Ali Masykur, 70 Persen Tambang Migas RI Dikuasai Asing, sumber: http://ekbis.rmol. co/read/2013/08/05/120963/Duh,-70-PersenTambang-Migas-RI-Dikuasai-Asing-

Sumardjono, Maria S.W., Penyempurnaan UUPA dan Sinkronisasi Kebijakan, Sumber: http:// www.kompas.com/kompas-cetak/0309/24/ opini/576798.htm 